\title{
Foreign Financial Inflows and Stock Market of the Host Country: Empirical Evidence from Pakistan
}

\author{
Sajjad Ali ${ }^{1}$ \\ Shahid Hussain Javaid ${ }^{2}$
}

\begin{abstract}
Foreign inflows play an important role in boosting the financial system and economic growth of a country. This paper aims to explore the impact of foreign financial inflows on the progress of stock market of a developing country like Pakistan. The study also intends to identify the relationship between foreign financial inflows and stock market development and to observe its short and long run dynamics. Variables like inflation, large scale manufacturing index and exchange rate are included in the study to determine stable stock market. For this purpose, monthly data from July 2001 till June 2012 is collected and analyzed through E-views statistical package. The vector error correction model (VECM), cointegration analysis and multiple regression analysis are opted for as part of methodology. The result shows that foreign financial inflows have a positive and significant impact on stock market returns. Moreover, the relationship between inflation and stock market returns is also positive, while there is a negative relationship of exchange rate and large scale manufacturing index with stock market returns. It is, thus, recommended that policies that attract foreign inflows should be pursued in order to improve stock market returns.
\end{abstract}

Keywords: Foreign financial inflows, host country, stock market returns

\section{Introduction}

Foreign Financial Inflows are believed to be facilitator for economic growth and the development of stock market. Stock market is an integral part of financial system and a strong financial system is essential for growth and stability. In the past decade Pakistan Economy's has witnessed some major shifts with an average GDP growth rate during 2001-04, 200508 and $2009-12$ remained $3.4 \%, 7.3 \%$ and $3.0 \%$ respectively. In the middle part of the decade the economy has shown better growth prospects due to some positive moves by the Government and support from foreign inflows in different forms. However, in the later part of the decade the growth has been sluggish. Similarly, the widely attributed 100 index of Karachi Stock Exchange also experienced some major movements in the past decade. In March-April 2005 the index shed almost 3000 points but regained its position and touched almost 16000 index points in April 2008. However, in January 2009 the market dipped to a decade lowest index of almost 5000 and started regaining its position until it touched an all time high index of more than 18000 recently. A variety of factors that may be held responsible are likely to be the privatization, war on terror, foreign inflows, power shortages, political changes, exchange and interest rate fluctuations, global financial crisis and so forth.

Amongst the three stock exchanges in Pakistan, Karachi Stock Exchange (KSE) is the oldest being the market leader having more than 600 listed companies with a total turnover of 21.2 billion shares as of July- March 2010-11 (Source: SECP, KSE) and more than 80 percent

\footnotetext{
${ }^{1}$ Sajjad Ali is Assistant Director, Accounts Department, State Bank of Pakistan, Peshawar, sajadmomand@yahoo.com ${ }^{2}$ Shahid Hussain Javaid is Joint Director, Research Department, State Bank of Pakistan, Karachi, shahid.hussain1@sbp.org.pk 
turnover of shares occurs at KSE (Raza et al., 2012). KSE has got four indices namely the KSE all shares index, KSE 100 index, KSE 30 index and KMI 30 index amongst which the KSE 100 index enjoys majority of the market share in terms of market capitalization (Cap). Foreign Direct Investment (FDI), Foreign Portfolio Investment (FPI), Remittances (Rem) etc. plays a very pivotal role in the Balance of Payment, Exchange rate stability and economic development of a country. Countries policy and transmission mechanism transpires the efficacy of foreign inflows. Consequently, being a leading indicator, the Stock Market also reflects such shifts and changes in the economy.

As a small open economy with foreign reserves of around 14 billion dollars, the influence of such inflows on Pakistan's economy and specifically on its Stock Market can be a hot topic of interest to be investigated.

\subsection{Research Problem}

Numerous researchers have assessed the impact of foreign investments separately on stock market. Studies like Wang and Shen (1999), took foreign investments, Adam and Tweneboah (2009), capture FDI and Exchange rate while Raza et al. (2012) consider FDI, Exchange Rate and inflation as factors affecting the stock market. On the other hand Anayochukwu (2012) has examined the effect of FPI and inflation on the stock market.

In the context of Pakistan no study has been found which examines the combined effect of FPI and FDI on stock market, so a need was felt to study the relationship between foreign financial inflows (taken as an aggregate of FPI, FDI and Foreign Remittances) and the Karachi stock market.

Specifically the study tried to;

- Observe the relationship between FFI and the stock market returns in Pakistan.

- Identify stock market returns determinants in Pakistan.

- Observe the short and long run dynamics of the variables.

The study will be beneficial for the policy makers, Government regulatory bodies, stock market participants and the students of economics and business discipline. The study will definitely add useful content to the existing literature and will try to identify certain grey areas for the future research. By utilizing this research better policy guidelines can be framed and more effective regulatory framework can be designed in the area of foreign inflows. Moreover, stock market participants can be able to do more prudent investment decisions with the help of this study. The study will definitely enhance the knowledge base of the students in the area under focus by adding value to the existing literature.

For the purpose of this study, market capitalization (CAP) has been used as dependent variable while Foreign Financial Inflows (FFI), PKR-USD exchange rate (EXR), Inflation (INF) and Large Scale Manufacturing (LSM) has been taken as independent variables. The market capitalization is used as a proxy for the stock market development/returns while the foreign financial inflows (FFI) is the aggregate of FDI, FPI and foreign remittances (Rem), however, the monthly large scale manufacturing index is used as proxy for GDP. The assumption behind using market capitalization as proxy for stock market returns is because of its less

\begin{tabular}{l|llll}
\hline 78 & July-December 2014 & Volume 12 & Number 2 & JISR-MSSE
\end{tabular}


arbitrary nature as compared to other measures of the stock exchange (Demirguc \& Levine, 1996) while the reason behind using LSM as proxy for GDP is that it is the only variable with the monthly data availability having maximum explanation of GDP.

The data used is of monthly frequency having sample of more than 130 observations monthly time series data ranging from July 2001 till June 2012 has been collected about the variables under study. The data has been collected from the publication of various reliable sources like State Bank of Pakistan, Karachi Stock Exchange, Pakistan Bureau of Statistics, websites of the organizations and in some cases through personal references of the researchers. Moreover, journals, books, newspapers, magazines and the internet have also been used as a secondary data sources for the literature review in order to develop an in-depth understanding about the topic under study. Based on the literature review the data has been analyzed through both descriptive and inferential statistical techniques using software packages (E-Views). The data was further analyzed through Vector Auto-Regression Model, Co-integration analysis of Johansen $(1988,91)$ and Multiple Regression analysis, as proposed and applied by other researchers on similar kind of studies.

\subsection{Stylized Facts}

The average annual GDP growth rate of Pakistan was about $4.9 \%$ in the last decade. The average monthly foreign inflows were Rs. 50606 million during the period of analysis whereas annual average rate of different foreign financial inflows remained at 7.7 as percent of GDP. The average FFI was highest during July-2009 to June 2011 while the average market capitalization was highest during July-2007 to June 2009.

First, the study assesses historical trend of financial inflows (FFI), market capitalization and nominal exchange rate.

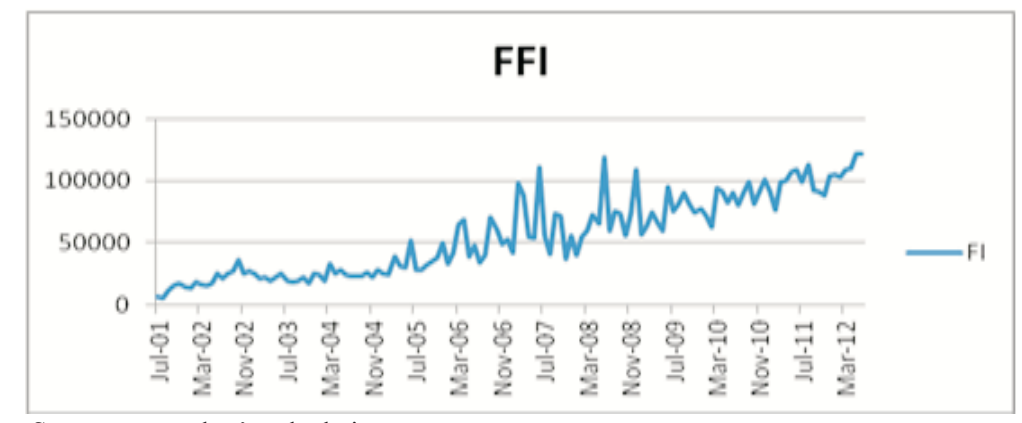

Source: researcher's calculations

\subsubsection{Historical Trends of Foreign Financial Inflows}

The foreign financial inflows are the aggregate of three components FDI, FPI and remittances. Pakistan received a total amount of Rs. 1770535 million net FDI during the period of analysis which is very low keeping in view its importance. The country received a total of Rs. 175796 million against FPI during the same period where as the total amount of remittance received during the period of analysis was Rs. 5266644 million. Moreover during 2001-2012 the country in total has received around Rs. 7212975 million from these three different sources. 
The graphical presentation of FFI below shows an increasing trend of the variable.

\subsubsection{Historical Trends of Stock Market Capitalization}

Pakistani stock market has been classified as one of the most viable and fast growing market. The market capitalization of KSE reached to almost Rs. 4,500,000 million in the first quarter of 2008. The KSE 100 index rose to 12,130 points on May 2008 as compared to 1521 points on June 2000, while in recent period the index touched more than 18,500 points. The graph below shows an increasing trend of the market capitalization however there is a decline after 2007 may be due to financial shocks in the international financial markets.

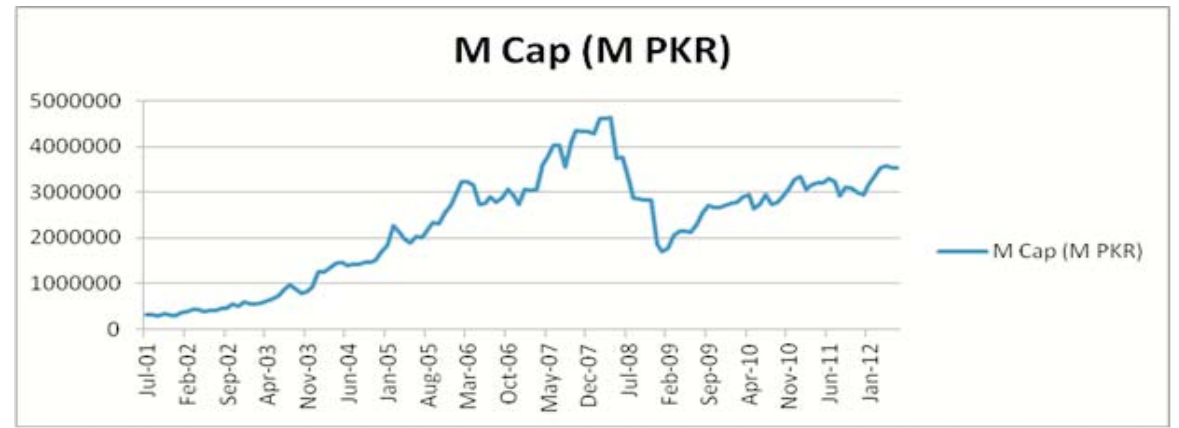

Source: KSE 2012

\subsubsection{Historical Trends of Nominal Exchange Rate}

Exchange rate is considered to take into account the inflation. The appreciation in exchange rate means the devaluation of local currency hence increase in domestic cost of producing goods as well as price imports. The exchange rate data series is taken the State Bank of Pakistan (SBP) data tables.

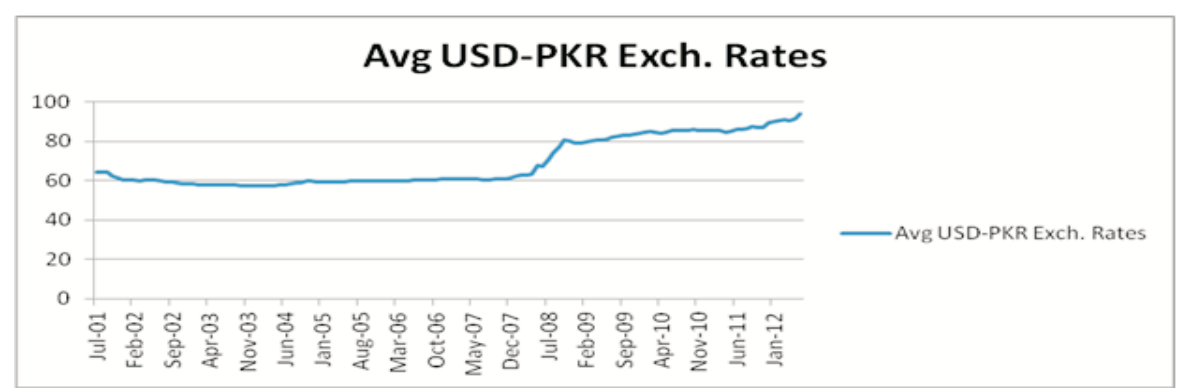

Source: SBP 2012

The graph shows that on average the exchange rate has increased from 2001 to 2012 and generally followed an upward trend. Continuous appreciation of exchange rate can be seen during the period under consideration.

\begin{tabular}{l|l}
\hline 80 & July-December 2014
\end{tabular}

Volume 12

Number 2

JISR-MSSE 


\section{Literature Review}

In the last couple of years, the financial/capital markets of the countries especially the developing one had shown a growing tendency specifically in their Stock Exchanges. A properly organized and managed stock exchange together with other internal variables attracts foreign investments in the country. According to Griffin and Pustay (2010), international/foreign investments can be defined as, capital supplied by residents of one country to residents of another. Foreign investments can be broadly categorized into two types a) Foreign Direct Investments (FDI) and b) Foreign Portfolio Investments (FPI). As explained by Rugman and Hodgetts (2002), FDI are the investments made for the purpose of control over investment /enterprises in the host country whereas FPI means the purchase of shares in foreign country without seeking control over investment. The net foreign investment is the difference of inflow and outflow of FDI and FPI.

There exists a debate going on the beneficial and adverse effects of Foreign Inflows. Believers of liberalization in foreign inflows view that the liquidity and efficiency of local markets are tends to be enhanced (Lim, Brooks \&Kim, 2008), while there is also a growing consensus that foreign inflows are not beneficial as shown by empirical results (Rodrick, 1998). However, international inflows have potential benefits for countries with sound macroeconomic policies and sophisticated institutions for reaping its benefits and minimizing risks. Market segmentation theories clarify that increase in share prices due to increased foreign participation can be explained by two factors. Initially, the increase in investor's base bring about increase in diversification and risk sharing while afterwards the flow of new investors reduces the liquidity risk (Wang, 2007).

The literature in the field of international economics has also affirmed that there exist a relationship between ffi and stock market. Raza, Jawaid and Afshan (2013), have established a strong and positive connection between FDI and the market using an eight variable model by applying regression technique. Likewise, a positive relationship over the long run has been found between the stock market development, foreign direct investment and Nominal Exchange rate in Ghana by applying the technique of co-integration established by Engle and Grenger (Adam \& Tweneboah, 2009). Similarly Nazir, Nawaz and Gilani (2010), established a positive and significant connection between foreign direct investment and economic growth. Kalim and Shahbaz (2009), Halalmeh and Sayah (2010) also opined that foreign direct investment positively impact the stock market.

Unlike FDI, the investors interested or involved in the foreign portfolio investment seek rapid returns of their investments which may give an indication about such investors to come in or exit from a market in a short period of time. Consequently, numerous countries are alarmed regarding the harmful repercussions of the foreign outflow from equity in a situation of crisis. Stiglitz (1998), while observing the developing countries, reported that there is additional requirement of controls mechanism for capital flow as the developing countries are more susceptible to changes in foreign and international flows. According to equity market segmented theory of Stulz (1995), the changes in the investor base with inclusion of foreign investors in the emerging markets will increase risk sharing and liquidity which will result in the fall of expected return and rise in prices. Richards (2005), while assessing the impact of foreign portfolio investments in Mexico has argued that foreign portfolio investments impact the stock market leading to higher expected return due to diversification and risk sharing. 
Hasan (2012) established that foreign remittances to Pakistan are used for all the three purposes i.e. household expenditures, savings and investments and validated that Pakistani remittance utilization depicts resemblance with the investment behavior in Mexico (Quinn, 2005). Another study by Adam and Tweneboah (2009), was about tier relationship between FDI and stock market, the essence of the study were, (i) FDI stimulates economic growth (ii) Economic growth promotes stock market development (iii) which shows that FDI encourages stock market development. A number of studies suggests that FDI encourages domestic private investment, creates new job opportunities, helps in the technological transfer and also enhancing the host country's overall growth of economy. Gupta (2006) established a long term impact of foreign capital inflows on increasing investor participation and stock market development. Richards (2005) observed that foreign investment helps in the growth of domestic stock market. They suggested that an increase in market capitalization through foreign investment inflows brings about approximately ten times increase in stock prices. It has also been established that growth and welfare in developing countries may be enhanced by financial liberalization in the long run (Kose, Prasad, Rogoff and Wei, 2006). Durham (2004) argued that economic growth in the host country could not be boosted directly by foreign portfolio investment only. While analyzing the increase in market capitalization of developed and developing countries, Singh and Weisse (1998) pointed out that portfolio capital flows to the developing countries have tremendously increased their market capitalization as compared to developed countries. If we look at the aggregate picture of the above inflows in the form of Foreign Inflows (FI), we may conclude that foreign inflows results in an increase in market capitalization, growth expansion and also encourages domestic private investment in the host country.

One measure of the economic stability of a country could be the exchange rate. A stable exchange rate may likely give a positive signal about the stable economic position of the country and can put a positive impact on its stock market by through multiple ways. No relationship was found between the stock exchange performance and domestic exchange rate in Brazilian economy over the long run using unit root and co-integration tests (Tabak, 2006). According to Dimitrova (2005), using open economy multivariate short-term model, focusing the United States and United Kingdom from 1990 to 2004 reveals that rise and fall of stock markets may likely be the outcome of appreciation and depreciation of exchange rate of that particular country. A mixed relationship has been found in Middle East countries between stock prices and exchange rate before and during financial crisis using multifactor determinants (Parsav and Lean, 2011). The depreciation in the domestic exchange rate reduces the stock returns of foreign investors thereby result in the decline of stock market established by a research which also suggests that no short run association has been observed between stock prices and exchange rate (Muhammad \& Rasheed, 2002).

Inflation rate is a measure of the changes in the prices of goods and services in an economy. The rate of inflation can be controlled through the tools of fiscal policy, monetary policy and the monetary policy rate keeping in view other aspects of the economy as well. Naceur, Ghazouani and Omran (2007), agrees that there exists a significant but negative impact of stability in the economy in terms of inflation rate on the stock exchange. Nevertheless, Kalim and Shahbaz (2009), observed that inflation has a minimal but positive impact on the stock exchange/market. Similarly, it has also been found that inflation and stock market are positively associated by arguing that Pakistani stock market provides investors a hedge against the inflation and thus becoming a safe place for investors to invest.

\begin{tabular}{l|llll}
\hline 82 & July-December 2014 & Volume 12 & Number 2 & JISR-MSSE
\end{tabular}




\section{Theoretical Framework}

Our model is formulated on the basis of the studies conducted by Froot et al. (2001), Raza et al. (2012) and Adam and Tweneboah (2009) which explains that stock market development is shaped by FDI, FPI, Savings, Exchange Rate and Inflation. The expected signs for FDI, FPI and Exchange rate are positive.

The identified model is a five variables model which hypothesizes that stock market development (market capitalization) is a function of aggregate inflows (FFI), nominal exchange rate of PKR-USD (ExR), economic growth (LSM) and inflation (Inf). The expected signs for FFI, ExR and LSM would be positive.

Moreover, Log-linear model specification has been used in this study. Ehrlich (1977) and Layson (1983) opined that log-linear model is not only superior to the linear form but its results are also favorable. Following equation is being modeled for checking the impact of foreign inflows on stock market development.

$\mathrm{LCAP}=\alpha+\mathrm{LFFI}+\mathrm{LEXR}+\mathrm{L}$ INF $+\mathrm{LLSM}+\mathrm{Ut}$

\section{Data Analysis and Discussions}

In the following section the data has been analyzed through descriptive and econometric techniques.

\subsection{Descriptive Statistics and Correlation}

The Descriptive statistics in Table-2 below exhibit the Jarque-Bera result, which means that all the variables follow normal distribution at $5 \%$ probability. Standard deviation is higher for all the series showing more volatility.

Table 1

Descriptive Statistics

\begin{tabular}{lrrrrr}
\hline & LCAP & LFFI & LINF & LEXR & LLSM \\
\hline Mean & 6.263741 & 4.656067 & 0.898207 & 1.83135 & 2.130011 \\
Median & 6.4326 & 4.727731 & 0.941892 & 1.783181 & 2.092892 \\
Maximum & 6.666028 & 5.08674 & 1.395466 & 1.973659 & 2.387592 \\
Minimum & 5.451418 & 3.732305 & 0.148742 & 1.758414 & 1.98407 \\
Std. Dev. & 0.336582 & 0.29774 & 0.265665 & 0.073253 & 0.110545 \\
Skewness & -1.061352 & -0.487195 & -0.543161 & 0.600614 & 0.668206 \\
Kurtosis & 2.834512 & 2.499933 & 2.917875 & 1.555277 & 2.060827 \\
Jarque-Bera & 24.93294 & 6.597258 & 6.527624 & 19.41596 & 14.67424 \\
Probability & 0.000004 & 0.036934 & 0.038242 & 0.000061 & 0.000651 \\
Sum & 826.8138 & 614.6009 & 118.5633 & 241.7382 & 281.1615 \\
Sum Sq. Dev. & 14.84065 & 11.61304 & 9.245724 & 0.70294 & 1.600832 \\
Observations & 132 & 132 & 132 & 132 & 132 \\
\hline
\end{tabular}

Source: Researcher's calculations on monthly data set of 12 years. 
As the mean and median values of all the variables are close to each other which shows that the values are evenly distributed and there are no outliers in the data which can be further verified from the maximum and minimum values. The values of the Standard Deviation for all the variables are less than .5 , which is also a positive sign about the normality of the data. The Skewness results for all the variables show that they are moderately skewed. Similarly the Kurtosis values of the variables also show that CAP, FFI and INF are Meso-kurtic while the EXR and LSM follow Platykurtic distribution.

Table 2

Correlation

\begin{tabular}{lrrrrr}
\hline & LCAP & LFFI & LINF & LEXR & LLSM \\
\hline LCAP & 1 & & & & \\
LFFI & 0.820294395 & 1 & & & \\
LINF & 0.766250441 & 0.736689294 & 1 & & \\
LEXR & 0.450692915 & 0.743331608 & 0.615130111 & 1 & \\
LLSM & 0.090121766 & -0.225384422 & -0.171259572 & -0.607399551 & 1 \\
\hline
\end{tabular}

Source: Researcher's calculations on monthly data set of 12 years.

The correlation matrix shows that there is positive correlation of all independent variables (FFI, INF, EXR, LSM) with the dependent variable (CAP). Correlation between CAP and FFI is 0.8 which is the highest as compared to INF, EXR and LSM.

\subsection{Testing for Stationarity}

The table given below shows the Augmented Dickey Fuller (ADF) Unit root estimation.

Table 3

Descriptive Statistics

\begin{tabular}{|c|c|c|c|c|c|c|c|c|}
\hline \multirow[t]{3}{*}{ Variables } & \multirow{2}{*}{\multicolumn{2}{|c|}{\begin{tabular}{|l|} 
Level \\
Intercept
\end{tabular}}} & \multicolumn{6}{|c|}{ First Difference } \\
\hline & & & \multicolumn{2}{|c|}{ Intercept and Trend } & \multicolumn{2}{|c|}{ Intercept } & \multicolumn{2}{|c|}{ Intercept and Trend } \\
\hline & t-Stat & Prob. Value & t-Stat & Prob. Value & t-Stat & Prob. Value & t-Stat & Prob. Value \\
\hline LCAP & -2.49 & 0.119 & -1.45 & 0.84 & -10.24 & 0.00 & -10.49 & 0.00 \\
\hline LFFI & -2.30 & 0.173 & -5.013 & .0004 & -14.74 & 0.00 & -14.77 & 0.00 \\
\hline LEXR & 0.717 & 0.992 & -2.459 & 0.348 & -4.594 & .0002 & -7.359 & 0.00 \\
\hline LINF & -1.556 & 0.502 & -1.824 & 0.688 & -9.834 & 0.00 & -9.802 & 0.00 \\
\hline LLSM & -2.313 & 0.17 & -2.702 & 0.24 & -13.28 & 0.00 & -13.28 & 0.00 \\
\hline
\end{tabular}

Source: Researcher's calculations at Critical value $\alpha=5 \%$

At intercept all the variables are stationary at level and none of them is significant, whereas at intercept and Trend FFI is significant at levels. On the other hand at first difference all the variables are significant at intercept and intercept and trend. This gives the signal that we may use techniques other than OLS.

\begin{tabular}{l|l}
\hline 84 & July-December 2014
\end{tabular}

Volume 12

Number 2

JISR-MSSE 


\subsection{OLS Estimates}

We estimated for OLS and all the variables were showing significant results. But after checking for the Unit Root test, some series were stationary at level and some at first difference. This violates the assumptions for OLS and thus other models like VAR, ARDL, GMM etc. should be used. As R-squared is considered as a fitness test of the model, here $\mathrm{n}$ this study the R-squared in the OLS estimation is about $90 \%$ which shows the strength of the model. Since dynamic correlations are significant at 1 st difference hence we estimate the VECM.

\subsection{Testing for Co integration}

Table 4

Un-restricted Co-integration Rank Test

\begin{tabular}{lllll}
\hline Hypothesized & & Trace & 0.05 & \\
\hline No. of CE(s) & Eigenvalue & Statistic & Critical Value & Prob. ${ }^{* *}$ \\
None ${ }^{*}$ & 0.333692 & 108.0868 & 69.81889 & 0 \\
At most 1 & 0.192142 & 55.3063 & 47.85613 & 0.0085 \\
At most 2 & 0.155175 & 27.56828 & 29.79707 & 0.0885 \\
At most 3 & 0.040259 & 5.646985 & 15.49471 & 0.7368 \\
At most 4 & 0.002344 & 0.305078 & 3.841466 & 0.5807 \\
\hline
\end{tabular}

Source: Researcher's calculations whereas, * shows level of significance at $*=1 \%, * *=5 \%, * * *=10 \%$

The co-integration results conducted for estimating the long run relationship between variables reveals that the co-integration exists in our data. Now we can estimate the VECM (Vector Error Correction Model). The advantages of the VECM are that it automatically caters the problem of multicollinearity, hetroskedasticity, autocorrelation and simultaneity.

\subsection{Vector Error Correction Estimates}

The VECM estimates generated for the long run reveals that all the variables were significant at 5\% confidence level except LSM. The results generated are in agreement with the results so generated by Adam and Tweneboah (2009) and Raza et al., (2012).

The results of the coefficients obtained are given below,

Cap $=4.72+1.8$ FFI -3.95 EXR + 0.43 Inf - 0.09LSM

This shows a positive relationship between Foreign Financial Inflows (FFI) and Market Capitalization (Cap), which states that a 1 percent increase in the FFI will result in approximately 1.8 percent increase in CAP on average. The relationship between CAP and INF was also positive which supports the study proposition of (Shahbaz, 2007), while there was a negative relationship between found between EXR, LSM and CAP.

Moreover, according to the short run estimates of the VECM only LSM was found significant. 


\subsection{VECM Estimates in Case of Excluding Foreign Remittances}

In this part we produced the results for Foreign Investments (FI= FFI-Rem) by excluding the foreign remittances from Foreign Financial Inflows (FFI=FDI+FPI+REM). It was observed that if we exclude the remittances from FFI even then our FI is significant with Market Capitalization (CAP) having positive coefficient for both. But the size of coefficient in case of FI was 1.8 while the same was 1.36 for FI.

The results of the coefficients obtained are given below,

Cap $=-1.7+1.36 \mathrm{FI}-0.26 \mathrm{INF}+2.32 \mathrm{EXR}-0.65 \mathrm{LSM}$

This shows a direct relationship between Foreign Investments (FI) and Market Capitalization (Cap), which states that a 1 percent increase in the NFI will result in approximately 1.36 percent increase in CAP on average. The relationship between CAP and EXR was also direct while there was an indirect relationship between found between INF, LSM and CAP.

\section{Conclusion}

The rationale behind this research is to investigate the role of foreign financial inflows on the stock exchange development/returns of a developing country like Pakistan. The aim was to determine whether the relationship between these two variables exists in Pakistan and further estimating and establishing the relationship between them. Other important variables like PKR-USD exchange rate, inflation and large scale manufacturing index were also included in addition to the focused explanatory variable FFI. By making use of the monthly data (time series) from July 2001 till June 2012 and applying the Johansen co-integration test, the results depicts evidence of co-integration verifying that there is a long run relationship between stock market returns and foreign financial inflows in Pakistan. The Vector Error Correction Model estimates suggest that all the variables were significant at $5 \%$ level of confidence except LSM. There is a positive significant impact of foreign financial inflows on stock market capitalization. The relationship between inflation and capitalization was also positive while the relationship of exchange rate and large scale manufacturing with capitalization was negative.

\subsection{Recommendations}

Based on the findings of the research, following recommendations are suggested,

- As foreign financial inflows has positive and significant impact on stock market returns in Pakistan thus such policies should be framed that will attract foreign inflows in order to boost stock market returns.

- Stable exchange rate is required to boost foreign inflows so that stock market is strengthened.

- Such economic reforms like minimizing the deficit in the balance of trade etc. must be made which target macroeconomic stability, removal of structural distortions and construction of business friendly environment to increase domestic production capacity. 
Monetary and fiscal policies should be anti-inflationary so that to discourage capital flight in the country.

- The supervisory and regulatory bodies in the financial system should be strengthened by tackling their governance issues.

\subsection{Areas of Future Research}

Future research can be done regarding the effects of shocks that whether the effect of positive and negative shocks of foreign inflows on stock market is asymmetric or not. By increasing the sample size or using high frequency data the research can be reproduced with more generalizable results.

\section{References}

Adam, M. A., \& Tweneboah, G. (2009). Foreign Direct Investment and Stock Market Development: Ghana's Evidence. International Research Journal of Finance and Economics, Iss. 26, 178-185.

Anayochukwu, B. O. (2012). The Impact of stock Market Returns on Foreign Portfolio Investments in Nigeria. IOSR Journal of Business and Management, 2(4), 10-19.

Raza, S. A., Jawaid, S. T., \& Afshan, S. (2013). Is Stock Market Sensitive to Foreign Capital Inflows and Economic Growth? Evidence from Pakistan.

Richards, A. (2005). Big fish in small ponds: The trading behavior and price impact of foreign investors in Asian emerging equity markets. Journal of Financial and quantitative Analysis, 40(01), 1-27.

Demirguc, K. A., \& Levine, R. (1996). Stock Market Development and Financial Intermediaries: Stylized Facts. World Bank Economic Review, 10(2), 291-321.

Dimitrova, D. (2005). The Relationship between Exchange Rates and Stock Prices: Studied in a Multivariate Model. Issues in Political Economy. 14, 1-25.

Durham, B. J. (2004). Absorptive Capacity and the Effects of Foreign Direct Investment and Equity Foreign Portfolio Investment on Economic Growth. European Economic Review, 48(2), 285-306.

Ehrlich, I. (1997). The Deterrent Effects of Capital Punishment Reply. American Economic Review, 67, 452-58.

Gupta, R. (2006). Benefits of diversification into emerging equity markets with changing correlations: An Australian perspective. International Review of Business Research Papers, 2(4), 22-38. 
Gilani, J. U., Nawaz, M. M., \& Nazir S. M. (2010). Relationship Between Economic Growth and Stock Market Development. African Journal of Business Management, 4(16), 3473-3479.

Griffin, W. R., \& Pustay, W. M. (2010). International Business, Sixth Edition, Prentice Hall: New Jersey.

Halalmeh, A. M., \& Sayah, M. A. (2010). Impact of Foreign Direct Investment on Shares Market Value in Amman Exchange Market. American Journal of Economics and Business Administration, 2(1), 35-38.

Hasan, M. S. (2012). Remittances Inflow in Pakistan as a Driver of Expenditures, Savings and Investment: An Investigation in the Behavior of the NBP's Clients.

Johansen, S., (1988). Statistical Analysis of Co-integrating Vectors. Journal of Economic Dynamics and Control, 12, 231-254.

Johansen, S., (1991). Estimation and Hypothesis Testing of Co-integrating Vectors in Gaussian Vector Autoregressive Models, Econometric, 59, 1551-1580.

Kalim, R., \& Shahbaz, M. (2009). Impact of Foreign Direct Investment on Stock Market Development: The Case of Pakistan. Global Conference on Business and Economics, ISBN 978-0-9742114-2-7.

Lim, K. P., Brooks, R. D., \& Kim, J. H. (2008). Financial crisis and stock market efficiency: Empirical evidence from Asian countries. International Review of Financial Analysis, 17(3), 571-591.

Kose, A. M., Prasad, E., Rogoff, S. K., \& Wei, J. S. (2006). Financial Globalization: A Reappraisal. NBER Working Papers, 12484.

Layson, S. (1983). Homicide and Deterrence: Another View of the Canadian Time Series Evidence, Canadian Journal of Economic, . 16, 52-73.

Wang, J. (2007). Foreign equity trading and emerging market volatility: Evidence from Indonesia and Thailand. Journal of Development Economics, 84(2), 798-811.

Muhammad, N., \& Rasheed, A. (2002). Stock Prices and Exchange Rates: Are they related? Evidence from South Asian Countries. The Pakistan Development Review, 41(4), 535 550 .

Naceur, B. S., Ghazouani, S., \& Omran, M. (2007). The Determinants of Stock Market Development in the Middle-Eastern and North African Region. Emerald Managerial Finance, 33(7), 477-499.

Parsva, P., \& Lean, H. H. (2011). The Analysis of Relationship between Stock Prices and Exchange Rates: Evidence from Six Middle Eastern Financial Markets. International Research Journal of Finance and Economics, 66, 157-171. 
Quinn, M. A. (2005). Remittances, Savings and Relative Rates of Return. Journal of Development Areas, 38(2), 1-23.

Raza, A., Iqbal, N., Ahmed, Z., Ahmed, M., \& Ahmed, T. (2012). The Role of FDI on Stock Market Development: The Case of Pakistan. Journal of Economics and Behavioral Studies, 4(1), 26-33.

Rugman, M. A., \& Hodgetts M. R. (2002). International Business, Third Edition, Prentice Hall, Inc.: New York.

Singh, A., \& Weisse, A. B. (1998). Emerging Stock Markets, Portfolio Capital Flows and Long-trem Economic Growth: Micro and Macro Perspectives. World Development, 26(4), 607-622.

Stiglitz, J. (1998). Boats, Planes and Capital Flows. Financial Times, March 25,1998.

Stulz, R. M. (1995). International Portfolio Choice and Assets Pricing. An Integrative Survey, in Jarrow et al eds Handbooks in Operations Research and Management Science. Finance: North Holland.

Tabak, M. B. (2006). The Dynamic Relationship between Stock Prices and Exchange Rates: Evidence for Brazil, International Journal of Theoretical and Applied Finance, 9(8), 1377-1396.

Wang, R. L., \& Shen, H. C. (1999). Do Foreign Investments affect Foreign Exchange and Stock Markets- The Case of Taiwan. Applied Economics, 31, 1303-1314. 


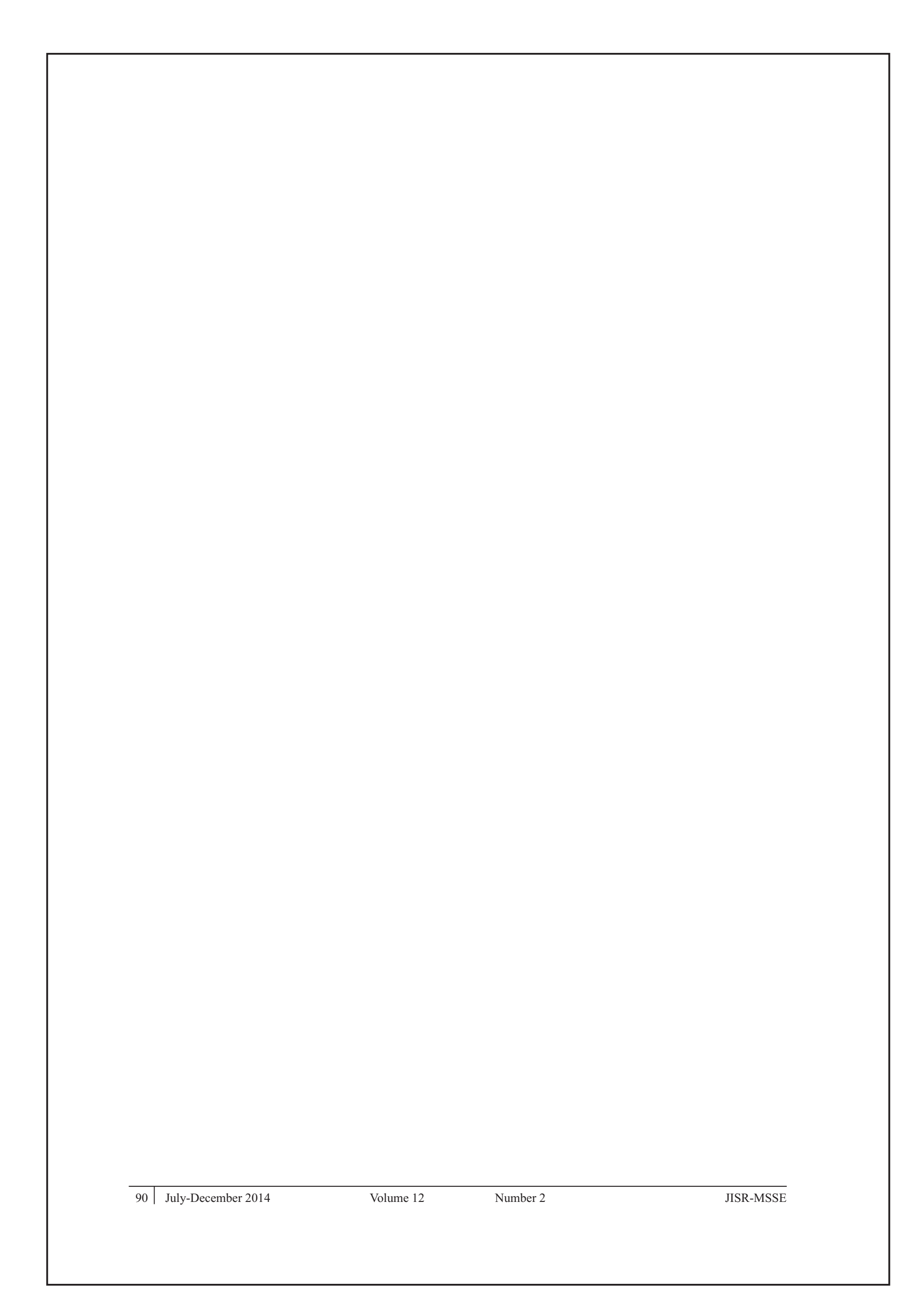

